Еще одним объектом исследования являлись слова, имеющие приставки (табл.3). В тексте таких слов было 20. Таким образом, самой распространенной является приставка un-. Эта приставка используется для образования отрицательной формы слова или его антонима. Чаще всего она присоединяется к прилагательным.

\title{
Заключение
}

Подводя итоги данной работы, отметим, что изученный текст описывает события, связанные с космосом, о чем и доказывает табл. 1, где наибольшее кол-во слов относится к предметной области «Космос».

Так же можно отметить, что чаще всего в тексте употребляются имена прилагательные, которые уточняют информацию, зафиксированную в текстах статьи на английском и русском языках.

В заключении отметим, что результаты исследования, в той или иной степени, перспективны для использования экологами, географами, лингвистами и другими специалистами, занимающимися проблемами предметной области «Космос». В будущем планируется продолжение исследования на выявление когнитивно-прагматических характеристик массива научных текстов по изучаемой теме.

$$
* * *
$$

1. Валентинова О.И. Денисенко В.Н., Рыбаков М.А. Актуальные направления современной лингвистики с позиций системного подхода. Некоторые размышления об итогах научной стажировки в РУДН «Общая и частная методология филологической науки» 2019 года // Вестник Российского университета дружбы народов. Серия: Теория языка. Семиотика. Семантика. 2021. Т. 12. № 3. С. 918-933. DOI: 10.22363/23132299-2021-12-3-918-933.

2. Думбровская П.М., Семенова С.Н. Географические термины в художественной литературе (на материале повести Т. Гарди «Три незнакомца» на английском и русском языках) // Экология языка: южнороссийский опыт межкультурной коммуникации: сб. ст. ІІ Южнорос. науч.-практ. конф. (15 декабря 2020 г.) / сост. В.Ю. Новикова. Краснодар: Краснодарский гос. ин-т культуры. 2020. С. 198-205.

3. Манн А. Венера может быть пригодной для жизни планетой: новые открытия ученых [Электронный ресурс] - Режим доступа: https://www.scientificamerican.com/article/venus-might-host-life-new-discovery-suggests/\# (дата обращения: 21.09.21).

4. Манн А. Венера может быть пригодной для жизни планетой: новые открытия ученых (перевод Юлия Гуркина) [Электронный ресурс] - Режим доступа: https://newochem.ru/kosmos/venera-mozhet-byt-prigodnojdlya-zhizni-planetoj-novye-otkrytiya-uchenyx/ (дата обращения: 21.09.21).

5. Семенова С.Н. Тезаурус жанра рассказ как произведения художественной литературы (на материале рассказов Дж. Лондона «Безмолвие» и «Сын Волка» на английском, армянском и русском языках) // Филологические науки. Научные доклады высшей школы. М.: АЛМАВЕСТ, 2017. № 2. С. 28-37. DOI: 10.20339/PhS.2-17.028.

6. Список суффиксов [Электронный ресурс] https://www.interactive-english.ru/tablitsy/285-suffiksy/ (дата обращения 20.10.21).

\section{Кандыбина А.B.}

Национально-культурная специфика паремичных единиц в рамках антиномии «умглупость» (на материале русского и чешского языков)

ФГАОУ «Волгоградский государственный университет» (Россия, Волгоград)

doi: 10.18411/trnio-12-2021-270

\section{Аннотация}

В работе представлена характеристика семантических особенностей русских и чешских паремий в рамках антиномии «ум-глупость». Описаны единицы с ядерным компонентом «религиозные представления». Установлены общие и специфические черты отражения национального менталитета в семантике пословично-поговорочных выражений сравниваемых языков.

Ключевые слова: паремия, ум-глупость, религиозные представления, менталитет, культура, пословица, поговорка. 


\section{Abstract}

The paper presents a characteristic of the semantic features of Russian and Czech paremias in the framework of the antinomy "mind - stupidity". Units with a nuclear component "religious ideas" are described. The general and specific features of the reflection of the national mentality in the semantics of proverbial and proverbial expressions of the compared languages have been established.

Keywords: paremia, mind-stupidity, religious ideas, mentality, culture, proverb.

В системе любого живого языка особое место занимает паремиологический пласт, который является своеобразным «хранилищем» единиц малого фольклорного жанра. Понятие паремии одновременно принадлежит и литературоведческому, и лингвистическому терминологическим аппаратам, в связи с чем обладает некой двойственностью и неопределённостью. В нашей работе паремия рассматривается как обобщающее понятие для пословиц и поговорок, отличительной особенностью которых признается назидательный характер и дидактичность. Употребление исследуемых языковых элементов в речевой практике позволяет в лаконичной форме передать некую систему ценностей и представлений, относящихся к контексту внеречевой действительности. Неслучайно О.С. Сергиенко замечает, что «...паремия сама по себе представляет собой, во-первых, особый самостоятельный контекст со своей внутренней формой, а также прямым и переносным значением, и, во-вторых, пословица сама является частью контекста» [Сергиенко, 2010 с. 273]. Носитель языка, используя пословицы и поговорки как своеобразные штампы, воспроизводит модель национального сознания и проецирует многовековой опыт народа на жизненные ситуации современности: «... пословицы, подобно словам, хранятся в языковой памяти того или иного народа» [Даниленко 2018, с. 74].

Следует учитывать, что представители разных этносов могут иметь полярные точки зрения на одинаковые явления и события. Это связано со спецификой мировоззрения, которое формировалась в результате сложного и длительного процесса развития того или иного народа. Исторические, экономико-политические, религиозные и даже природные факторы оказывали непрерывное влияние на становление национального менталитета. По утверждению М.В. Миловановой, «в связи с этим весьма актуальным является исследование проблемы отражения в семантике языковых единиц национально-культурных особенностей» [Милованова 2007, с. 3]. Особое внимание в рамках данного исследовательского поля привлекает изучение родственных языков, которые сохранили отпечаток прошлого единства. Русский и чешский языки как представители восточнославянской и западнославянской групп соответственно дают богатый материал для сопоставительного анализа единиц паремиологического фонда.

Религиозные представления занимают особое место в сознании представителей народов, исповедующих христианство. Связь с богом или дьяволом влияет на объяснение умственных способностей человека. В рамках антиномии «ум-глупость» встречаются не только лексемы бог, господb, но и наименования составных частей христианских храмов, названия церковных таинств и производных от них; употребляется лексема с просторечным оттенком non. Отношение Бога к человеку, лишенному разума или обладающему в малой степени интеллектом, является снисходительным, покровительственным: на дурака у Бога милости много. Тем не менее, за прегрешения Бог может отнять ум у человека, сделать его глупым: кого хочет Бог наказать, у того отнимает разум. Однако даже глупые люди никогда не забывают божественные праздники, что указывает на общеизвестность и значимость религиозных событий в жизни каждого человека: И дурак знает, что в Христов день праздник. Однако не всегда такой человек в силу отсутствия логического мышления и ответственности за свои действия способен покориться Господу: В дураке и бог не волен. Это выражает двоякое отношение русского народа к связи между глупцом и божественными силами. Помимо простой констатации глупости в паремиях могут быть запечатлены основные качества глупых людей: везение, доверчивость, доброта, неспособность к обиде. Например, в пословицах Заставь дурака богу молиться, он и лоб разобьет и Дураку хоть плюй в глаза, а ему божия роса внимание акцентируется на буквальном восприятии глупым 
человеком обращенных к нему просьб, а также на его отходчивом характере. Из-за подобных качеств глупые люди часто оказываются притесненными в обществе и неспособными отстоять свою точку зрения. В поговорке Дурака и в алтаре бьют даже священное место в храме оскверняется людской злостью и несдержанностью по отношению к человеку, лишенному ума. Важным с точки зрения семантики является приравнивание дурака и священнослужителя, который в русских паремиях обладает слабым умом: Попа да дурака - 8 передний угол сажают; Глупый поп свенчает, умному не развенчать.

Во всех представленных пословицах и поговорках активно используется лексема дурак, которая имеет негативную сниженную коннотацию и лаконично характеризует глупого человека. Умный человек рассматривается как думающий о душе и осмысливающий свою жизнь; в религиозном смысле он готов бороться с грехами и исповедовать их перед богом: Умный и согрешит, и поправит. В данной пословице грех мыслится как неизбежный компонент мирской жизни, но в умный человек в отличие от глупого всегда способен признать и исправить ошибку.

Среди чешских пословиц и поговорок преимущество отдаётся уму как варианту проявления божьего благословления на человеке. Лексема bi̊h употребляется в пределах одной паремии с лексемой rozum, что говорит о причинно-следственной связи между этими понятиями. Люди, не забывающие о Господе, всегда имеют способность последовательно мыслить; видеть в своей жизни божий промысел: Vš s bohem a rozumem (Bce с богом и с разумом); Rozumná hlavo, rozjímej díla boží (Умная голова, пойми божьи дела). Тем не менее, человеческий ум по силе не равен божественному разуму; первый всегда подчинен последнему, зависим от него: Bůh rozum lidský převyšuje (Бог превышает людской ум). В одном ряду с умом в чешской лингвокультуре находится мудрость, под которой понимается не уровень образованности, а жизненный опыт и бытовые знания: Moudrý jest $i$ bohu svat (Мудрый и Богу свят). Более того, данное качество связано со светлыми внеземными силами, которые противостоят темной стороне. Это выражено лексемами svět и tma, которые соответственно соотносятся с умом и глупостью: Na moudrých lidech svět stoji, a na bláznech tma (На мудрых людях стоит свет, на дураках тьма).

В фактическом материале обнаружены паремичные единицы, имеющие идентичную семантику и схожую структуру с русскими пословицами и поговорками: Koho pán bi̊h potrestati chce, nejperv mu rozum vezme (рус. Кого хочет Бог наказать, у того отнимает разум); $S$ bláznem ani pán bůh nic nepořídí (рус. В дураке и бог не волен).

В результате проведенного анализа были получены следующие результаты: паремичные единицы русского и чешского языков ярко репрезентируют специфику этнического мировоззрения. Семантические особенности рассмотренных пословиц и поговорок позволяют сказать, что в русской паремике встречается разнообразный круг образов, более богатый, чем в чешском языке. Среди схожих черт следует отметить активное функционирование лексемы дурак (в русском языке) и схожих по семантике лексических единиц в чешских паремиях, а также представленность полностью эквивалентных пословиц, что указывает на общее паремиологическое «прапространство» славянских языков. Важным отличием является разное направление векторов выражения ума и глупости: в русских паремиях акцент устанавливается на низком интеллекте человека; в чешских пословицах и поговорках наибольший интерес представляет ум.

1. Даниленко, В.П. О пословичной картине мира // Crede Experto: транспорт, общество, образование, язык. 2018. №1. С. $62-76$.

2. Милованова, М. В. Лингвокультурологические характеристики категории посессивности в русском и немецком языках : специальность 10.02 .20 «Сравнительно-историческое, типологическое и сопоставительное языкознание» : автореферат диссертации на соискание ученой степени доктора филологических наук / Милованова Марина Васильевна ; Волгоградский государственный педагогический университет. - Волгоград, 2007. - 44 с.

3. Сергиенко, О.С. Семантические преобразования пословиц на материале чешского и русского языков // Вестник ЛГУ им. А.С. Пушкина. 2010. №1. С. 272-280. 